\title{
zVAD-induced necroptosis in L929 cells depends on autocrine production of TNF $\alpha$ mediated by the PKC-MAPKs-AP-1 pathway
}

\author{
Y-T Wu ${ }^{1}$, H-L Tan ${ }^{1}$, Q Huang ${ }^{1}$, X-J Sun ${ }^{2}, X$ Zhu ${ }^{2}$ and H-M Shen ${ }^{\star, 1,3}$
}

It is intriguing that some pan-caspase inhibitors such as ZVAD-fmk (ZVAD) are capable of inducing necrotic cell death in a selected group of cells. As earlier reports from our laboratory have ruled out the original notion that zVAD-induced necrosis in mouse fibrosarcoma L929 cells was autophagic cell death, the main objective of this study was thus to determine the underlying mechanism of this form of cell death. In this study, we provided clear evidence that ZVAD-induced necroptosis in L929 cells and such cell death is dependent on autocrine production of tumor necrosis factor- $\alpha$ (TNF $\alpha$ ) at the transcriptional level. More importantly, we identified that activating protein-1 (AP-1), but not nuclear factor $\kappa-\mathrm{B}$, is the transcription factor controlling zVADinduced TNF $\alpha$ transcription. Moreover, zVAD is able to activate AP-1 through activation of two upstream mitogen-activated kinases (MAPKs), C-Jun N-terminal kinase and extracellular signal-regulated kinase. Finally, we found that protein kinase $\mathrm{C}$ is the important upstream signaling molecule in mediating ZVAD-induced activation of MAPKs and AP-1, and subsequent autocrine production of TNF $\alpha$ and cell death. Data from this study reveal the molecular mechanisms underlying zVAD-induced necroptosis, an important form of programmed necrotic cell death with increasing understanding of its biological significance in health and diseases.

Cell Death and Differentiation (2011) 18, 26-37; doi:10.1038/cdd.2010.72; published online 11 June 2010

On the basis of the morphological and biochemical features, programmed cell death (PCD) can be classified into three categories: apoptosis, autophagic cell death, and necrosis. ${ }^{1}$ The autophagic cell death has been described as a nonapoptotic cell death that is caused by excessive induction of autophagy ${ }^{2,3}$ On the other hand, there are several types of programmed necrosis described in the literature, including necrosis induced by ATP depletion, ${ }^{4}$ and necroptosis initiated by engagement of death receptors with their corresponding ligands, such as tumor necrosis factor- $\alpha($ TNF $\alpha){ }^{5}$

$\mathrm{TNF} \alpha$ is a pleiotropic proinflammatory cytokine that is capable of triggering multiple signaling pathways to regulate various physiological and pathological cellular processes. One important biological function of $T N F \alpha$ is to induce apoptosis by the extrinsic pathway. ${ }^{6}$ On the other hand, TNF $\alpha$ has also been demonstrated to trigger programmed necrosis, or necroptosis, in a number of cell types. ${ }^{7-10}$ The execution of necroptosis requires the kinase activity of receptor-interacting protein 1 (RIP1) and can be blocked by the RIP1 kinase inhibitor, necrostatin-1. ${ }^{9-11}$ At present, how RIP1 controls necroptosis is largely unknown. One possibility is that RIP1 may promote intracellular ROS production and c-Jun
$\mathrm{N}$-terminal kinase (JNK) activation by the activation of Nox1 NADPH oxidase. ${ }^{12}$ Recently, RIP3 has been identified as another crucial factor in TNF $\alpha$-induced necrotic cell death by interacting with RIP1. ${ }^{8,13,14}$ In TNF $\alpha$-mediated necroptosis, there is one intriguing observation: blockage of caspase cascade by either chemical inhibitors or overexpression of a viral caspase inhibitor (CrmA) greatly promotes the cell death. ${ }^{15,16}$ The exact mechanisms underlying such a sensitization effect are not known. As caspase 8 has been shown to cleave RIP1 in TNF $\alpha$ signaling, ${ }^{17}$ one possibility is that suppression of the caspase cascade would enhance the RIP1 protein stability and then promote RIP1-mediated necroptosis.

Among many types of caspase inhibitors, zVAD-fmk (zVAD) is probably the most commonly used pan-caspase inhibitor. Interestingly, although zVAD has been demonstrated to be of low cytotoxicity to most of cell lines in vitro, ${ }^{18}$ it can induce robust necrotic cell death in certain cell lines, particularly in L929 cells. ${ }^{19,20}$ Such necrosis was originally recognized as an autophagic cell death evidenced by a massive accumulation of the autophagic markers in the dying cells. ${ }^{19}$ However, our earlier works have provided compelling

${ }_{1}^{1}$ Department of Epidemiology and Public Health, Yong Loo Lin School of Medicine, National University of Singapore, Singapore; ${ }^{2}$ School of Medicine, Zhejiang University, Zhejiang, Hangzhou 310058, People's Republic of China and ${ }^{3}$ NUS Graduate School for Integrative Sciences and Engineering, National University of Singapore, Singapore 117597, Singapore

${ }^{*}$ Corresponding author: H-M Shen, Department of Epidemiology and Public Health, Yong Loo Lin School of Medicine, National University of Singapore, 16 Medical Drive, Singapore 117597, Singapore. Tel: 656516 4998; Fax: 656779 1489; E-mail: ephshm @nus.edu.sg

Keywords: zVAD-fmk; autocrine production of TNF $\alpha$; necroptosis; L929 cells; PKC; AP-1

Abbreviations: TNF $\alpha$, tumor necrosis factor- $\alpha$; FADD, fas-associated death domain; TRAIL, TNF-related apoptosis-inducing ligand; RIP1, receptor-interacting protein 1; RIP3, receptor-interacting protein-3; AP-1, activating protein-1; JNK, c-Jun N-terminal kinase; MAPK, mitogen-activated protein kinase; IKK, I- $\kappa$ B kinase; TNFR1, TNF receptor-1; ERK, extracellular signal-regulated kinase; NF- $\kappa \mathrm{B}$, nuclear factor $\kappa-B$; PKC, protein kinase C; PARP-1, poly(ADP-ribose)polymerase-1; TPA, 12-0-tetradecanoylphorbol-13-acetate

Received 21.8.09; revised 09.4.10; accepted 12.4.10; Edited by P Vandenabeele; published online 11.6.10 
evidence that zVAD-induced cell death in L929 cells is not autophagy-dependent; instead, autophagy has a protective function for cell survival. ${ }^{20,21}$ Therefore, the pro-death mechanism in zVAD-mediated necroptosis remains to be examined.

In this study, we demonstrate that autocrine production of TNF $\alpha$ is required for $z V A D$-induced necrotic cell death in L929 cells. Furthermore, zVAD-mediated autocrine production of TNF $\alpha$ is achieved by the activation of the protein kinase $C$ (PKC)-mitogen-activated protein kinases (MAPKs)-activating protein-1 (AP-1) signaling pathway. Data from this study thus provide new insights into the molecular mechanisms underlying zVAD-induced necroptosis, an important form of PCD with increasing understanding of its biological significance in health and diseases.

\section{Results}

zVAD-fmk and BocD-fmk, but not QVD-oph, induce necrosis in L929 cells. zVAD-fmk (zVAD) is a wellestablished general caspase inhibitor to block apoptosis. Intriguingly, zVAD is also capable of efficiently inducing necrotic cell death in a selected group of cell types, particularly in L929 cells. ${ }^{19,20}$ In this study, we first asked whether other caspase inhibitors possess the similar activity as zVAD for induction of necrosis. As shown in Figure 1a, among the caspase inhibitors tested, only zVAD-fmk and BocD-fmk were able to induce evident cell death in L929 cells. Interestingly, QVD-oph, another pan-caspase inhibitor that has been reported to be more efficient and of broaderspectrum than zVAD-fmk and BocD-fmk for caspase inhibition, ${ }^{22}$ was unable to induce cell death (Figure 1a) The effectiveness of all these caspase inhibitors was confirmed by their inhibitory effects on TNF-related apoptosisinducing ligand (TRAIL)-induced cleavage of caspase 8, caspase 3, and poly(ADP-ribose)polymerase-1 (PARP-1) in L929 cells (Figure 1b). Among the caspase inhibitors tested above, the fmk group has been demonstrated to be much more cytotoxic than oph. ${ }^{18} \mathrm{We}$ thus tested whether it is the fmk group that confers zVAD-fmk and BocD-fmk the killing ability. First, we found that neither zFA-fmk (a non-caspase inhibitor carrying fmk group) alone nor zFA-fmk plus QVD-oph induces cell death (data not shown). Next, the two caspase 8 inhibitors with different tags, IETD-fmk and IETD-oph, were found to induce marginal necrosis in L929 cells (Figure 1a). Moreover, at the same concentration, IETD-oph was slightly more toxic than IETD-fmk (Figure 1a). These results therefore negate the possibility that it is the fmk group leading to the cell death.

In an earlier report, the killing ability of ZVAD was attributed to its caspase 8 inhibition effect. ${ }^{19}$ In this study, we further examined this by overexpression of $\mathrm{CrmA}$, a viral protein known to specifically inhibit caspase $8 .^{23}$ As shown in Figure 1c, overexpression of CrmA (indicated by co-transfected GFP fluorescence) in L929 cells led to no cell death, whereas CrmA greatly enhanced cell death in the cells treated with exogenous TNF $\alpha$, being consistent with earlier observations. ${ }^{16}$ Furthermore, knockdown of caspase 8 or fas-associated death domain (FADD) did not kill L929 cells
(Supplementary Figure S1b), while effectively suppressed TRAIL-induced caspase 3 and PARP-1 cleavage, and apoptosis (Supplementary Figure S1a, S1b). Taken together, all these findings clearly suggest that inhibition of caspase 8 alone is not sufficient for zVAD to induce cell death in L929 cells.

zVAD-induced necrotic cell death requires de novo protein synthesis. To further understand the mechanisms underlying zVAD-induced cell death, we then tested whether de novo gene transcription and protein synthesis are required for such cell death. As shown in Figure 1d, actinomycin D (ActD) or cycloheximide (CHX) offered perfect protection against $z V A D$-induced cell death. In contrast, ActD or $\mathrm{CHX}$ markedly enhanced TNF $\alpha$-induced cell death in L929 cells (data not shown), indicating that their protective effect is specific to zVAD-induced cell death. These results thus suggest that $z V A D$-induced necrotic cell death requires de novo gene transcription and protein synthesis.

Another interesting and accidental finding is that the volume of cell culture medium affects zVAD-induced cell death. As shown in Figure 1e, when L929 cells were cultured in different volume of medium containing the same final concentration of $\mathrm{zVAD}(10 \mu \mathrm{M})$, the cell death was found to be mitigated by increasing medium volume. In contrast, alterations of medium volume did not affect cell death induced by exogenously administered TNF $\alpha$ (Figure 1e). It is thus possible that some newly synthesized proteins are secreted into the medium to trigger the cell death signaling pathway.

zVAD-induced cell death is RIP1- and RIP3-dependent. It has been well-established that RIP1 has a critical function in TNF $\alpha$-induced necroptosis and that necrostatin-1, a specific RIP1 kinase inhibitor, can suppress necroptosis. ${ }^{24}$ In this study, necrostatin-1 was found to be effective in suppressing cell death induced by zVAD, similar to that induced by TNF $\alpha$, but not in MNNG-induced necrosis which has been reported to be mediated by PARP-1 overactivation (data not shown). On the other hand, RIP3 has recently been identified as a key modulator in TNF $\alpha$-induced necroptosis. $^{8,13,14}$ In this study, we also tested whether RIP3 is involved in zVAD-fmk-induced cell death. As shown in Supplementary Figure S2, knockdown of RIP3 significantly reduced cell death induced by $\mathrm{ZVAD}$ or TNF $\alpha$, while displayed no effect on TRAIL-induced apoptosis. It is thus believed that zVAD-induced cell death is similar to TNF $\alpha$ induced necroptosis involving both RIP1 and RIP3.

zVAD promotes autocrine production of TNF $\alpha$. L929 cells are well known to produce a variety of cytokines, including $\mathrm{TNF} \alpha .{ }^{25}$ Moreover, autocrine production of TNF $\alpha$ has been recently recognized as a critical signal for the induction of apoptosis in response to Smac-mimetics or IAP antagonists. $^{26-28}$ In this study, we hypothesized that autocrine production of TNF $\alpha$ is involved in zVAD-induced necrotic cell death. A very low basal level of TNF $\alpha$ (around $3 \mathrm{pg} / \mathrm{ml}$ ) was detected in the medium (Figure 2a), while the TNF $\alpha$ level was markedly increased upon zVAD treatment for $8 \mathrm{~h}$ (Figure $2 \mathrm{~b}$ ). The drop of TNF $\alpha$ concentration at $24 \mathrm{~h}$-time point was 
probably due to cell death as shown earlier. Meanwhile, pretreatment with $\mathrm{CHX}$ totally abrogated the autocrine production of TNF $\alpha$ (Figure 2b). Next, we checked TNF $\alpha$ mRNA level using RT-PCR. As shown in Figure 2c, there was a higher level of TNF $\alpha$ mRNA in zVAD-treated cells than that in control cells. More importantly, both zVAD-fmk and BocD-fmk, but not QVD-oph, enhanced the transcription of TNF $\alpha$ (Figure 2c) and accordingly, autocrine production
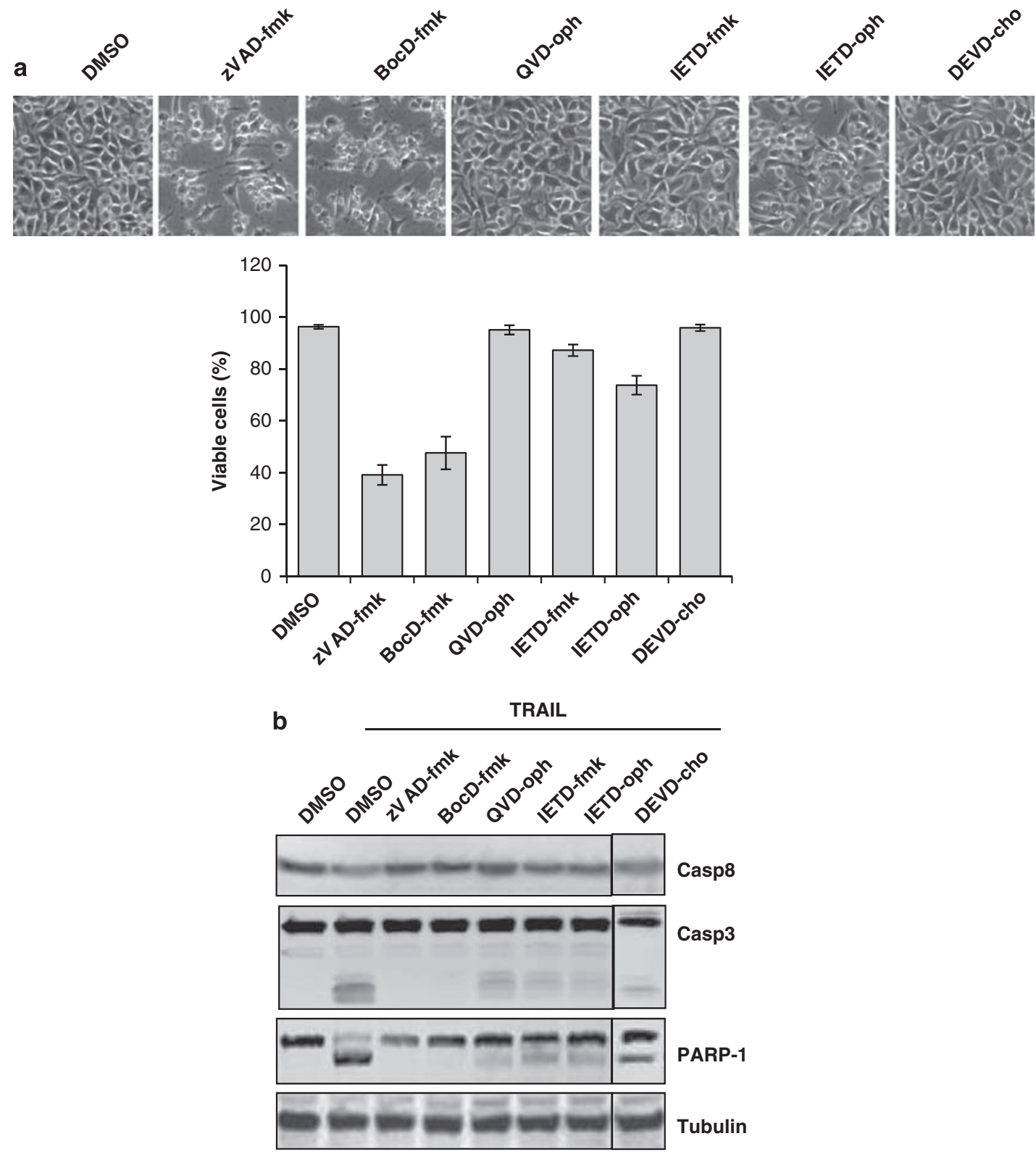

Figure 1 zVAD-fmk (zVAD) and BocD-fmk (BocD), but not QVD-oph (QVD), induce necrosis in L929 cells. (a) Effects of various caspase inhibitors on cell death. L929 cells were treated with zVAD $(10 \mu \mathrm{M})$, QVD $(20 \mu \mathrm{M})$, BocD $(10 \mu \mathrm{M})$, IETD-fmk $(20 \mu \mathrm{M})$, IETD-oph $(20 \mu \mathrm{M})$, and DEVD-cho $(100 \mu \mathrm{M})$ for $24 \mathrm{~h}$. Cell death was examined under microscope $(\times 200)$ for morphological changes (upper panel) and quantified by the PI exclusion assay (lower panel) (data were presented as mean \pm S.D. from three independent experiments). (b) Effects of caspase inhibitors on TRAIL-induced caspase and PARP-1 activation. L929 cells were pretreated with the caspase inhibitors as described in panel a for $1 \mathrm{~h}$, followed by treatment with TRAIL $(20 \mathrm{ng} / \mathrm{ml})$ for $8 \mathrm{~h}$. Cell lysate was subjected to western blotting. (c) Overexpression of CrmA is not sufficient to induce cell death in L929 cells. Cells were co-transfected with CrmA and EGFP (10:1), $24 \mathrm{~h}$ later, cells were treated with TNF $\alpha(10 \mathrm{ng} / \mathrm{ml} \times 6 \mathrm{~h})$ or remained untreated for another $24 \mathrm{~h}(\mathrm{Ctr})$, cell death was examined under a fluorescence microscope $(\times 400)$ and was quantified by counting the dead cells with green color (with a morphology of rounded or floated) in randomly selected 100 green cells (data were presented as mean \pm S.D. from three independent experiments). (d) De novo protein synthesis is required for ZVAD-induced cell death. L929 cells were pretreated with $\mathrm{CHX}(10 \mu \mathrm{g} / \mathrm{ml})$ or ActD $(5 \mu \mathrm{g} / \mathrm{ml})$ for $30 \mathrm{~min}$, followed by treatment with ZVAD $(10 \mu \mathrm{M})$ for $24 \mathrm{~h}$. The cell death was examined as described in panel a. (e) zVAD-induced cell death is affected by the volume of culturing medium. L929 cells were treated with different volumes of culturing medium $(300,600$, and $1000 \mu$ l per well for 24-well plates) containing the same concentration of ZVAD (10 $\mu \mathrm{M})$ or TNF $\alpha(10 \mathrm{ng} / \mathrm{ml})$ for 24 or $8 \mathrm{~h}$ respectively. The cell death was examined as described in panel a 
C

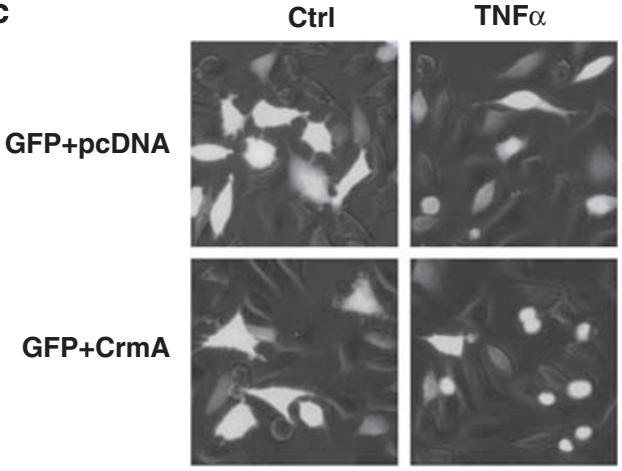

d

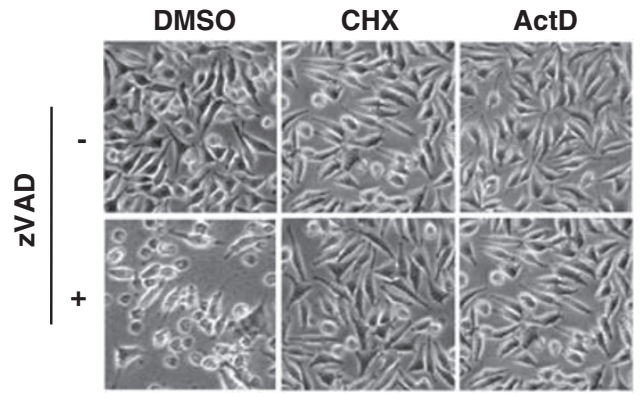

e

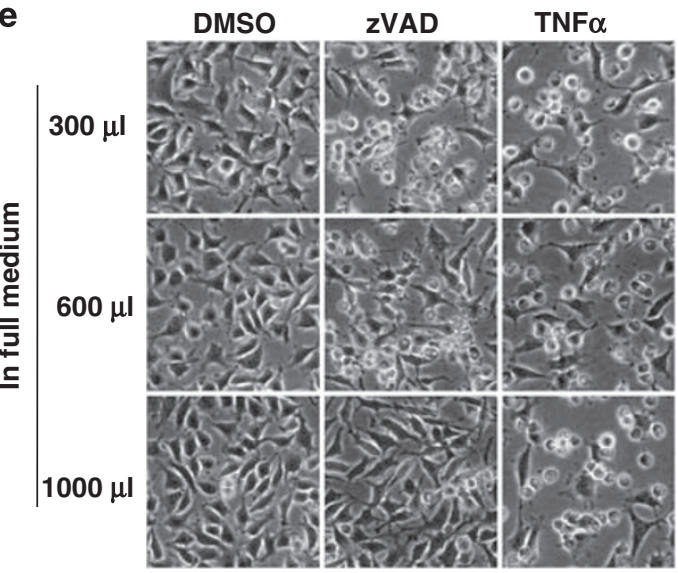

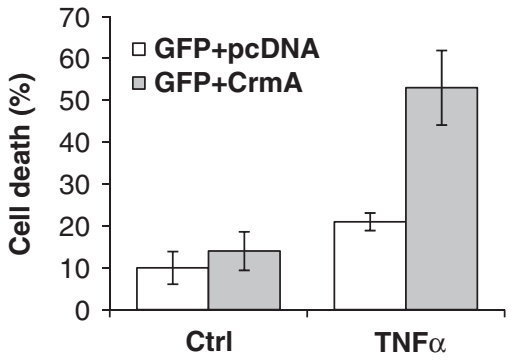

๑-zVAD $\square+$ +ZVAD

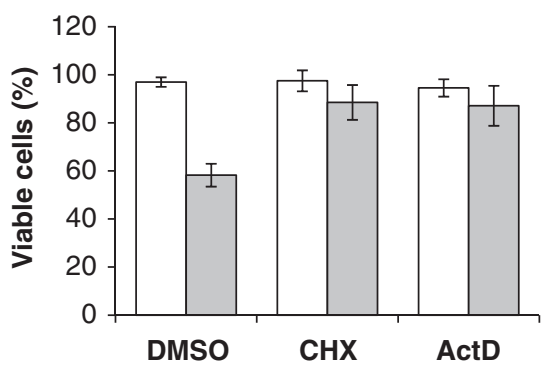

$\square 300 \mu \mathrm{l} \square 600 \mu \mathrm{l}=1000 \mu \mathrm{l}$

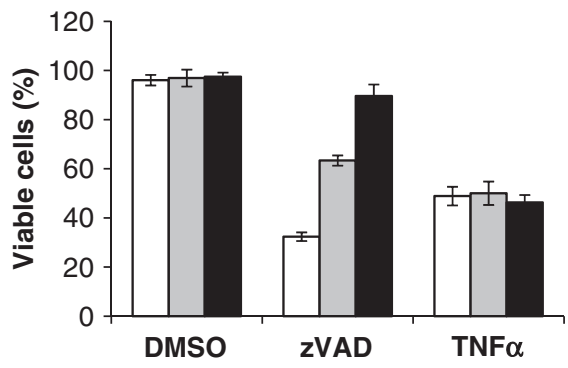

Figure 1 Continued

of TNF $\alpha$ in the medium (Figure 2d). Such findings are also consistent with the pattern of cell death induced by these caspase inhibitors as shown in Figure 1a.

Blockage of TNF $\alpha$ signaling suppresses zVAD-induced necroptosis. To test whether zVAD-induced autocrine production of $T N F \alpha$, as shown above, is required for cell death, we first intercepted the TNF $\alpha$ signaling by blocking TNF $\alpha$ receptor 1 (TNFR1) using a TNFR1 blocking antibody. It is to be noted that this antibody dose-dependently suppressed zVAD-induced cell death (Supplementary Figure S3a). As expected, this antibody also prevented exogenous TNF $\alpha$-induced cell death, without showing any protection against TRAIL-induced apoptosis in L929 cells (Supplementary Figure S3a). Moreover, a TNF $\alpha$-neutralizing antibody that specifically neutralizes the TNF $\alpha$ ligand in culture medium also ablated zVAD-induced cell death dose-dependently (Supplementary Figure S3b). In an attempt to seek further supporting evidence, we next used XENP1595, a DN-TNF protein against soluble TNF $\alpha$ as reported previously. ${ }^{29}$ As shown in Supplementary Figure S3c, XENP1595 offered perfect protection against cell death induced by zVAD and exogenous TNF $\alpha$. Collectively, these data clearly demonstrate that zVAD-induced necrotic cell death in L929 cells is necroptosis that depends on autocrine production of TNF $\alpha$. Remarkably, such findings are consistent with a recent report in which autocrine production of $\mathrm{TNF} \alpha$ was identified, through a genome-wide RNAi library screening, to be required for zVAD-induced cell death in $\mathrm{L} 929$ cells. ${ }^{30}$

Nuclear factor- $\kappa \mathrm{B}(\mathrm{NF}-\kappa \mathrm{B})$ pathway is not involved in zVADinduced autocrine production of $\mathrm{TNF} \alpha$, but has a protective 

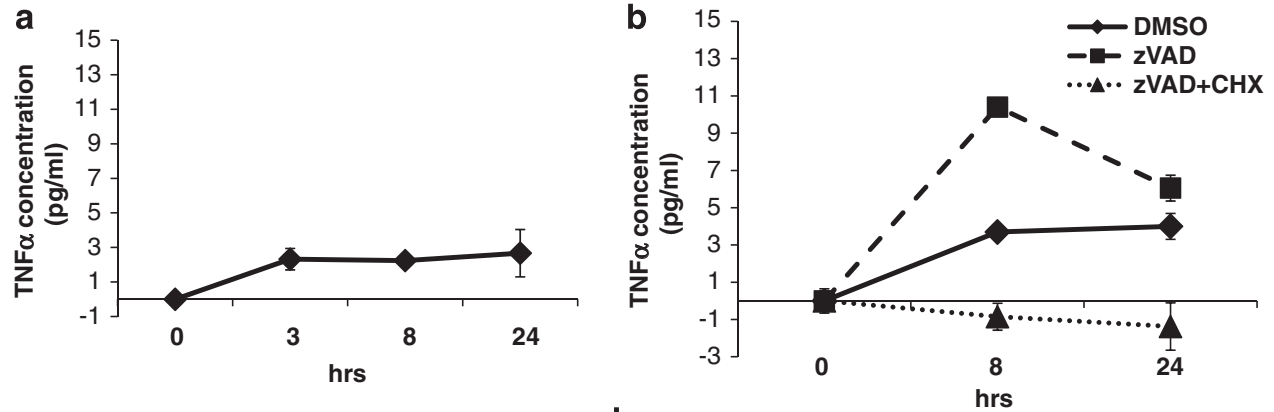

C

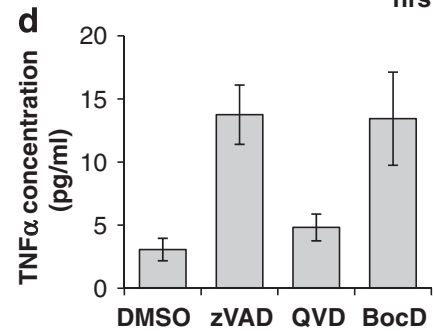

Figure 2 zVAD-fmk (zVAD) promotes autocrine production of TNF $\alpha$. (a) Basal level of autocrine TNF $\alpha$ secreted in culturing medium in untreated cells. L929 cells were washed with PBS twice and incubated in fresh medium for up to $24 \mathrm{~h}$, and the secreted TNF $\alpha$ in the medium was determined by ELISA. (b) zVAD enhances autocrine production of TNF $\alpha$ in culturing medium. L929 cells were incubated in fresh medium containing zVAD (10 $\mu \mathrm{M})$ or zVAD $+\mathrm{CHX}(10 \mu \mathrm{g} / \mathrm{ml})$ for up to $24 \mathrm{~h}$. The TNF $\alpha$ level was measured by ELISA. (c) zVAD and BocD-fmk (BocD), but not QVD-oph (QVD), promote TNF $\alpha$ transcription. L929 cells were treated with zVAD (10 $\mu \mathrm{M}), \mathrm{QVD}(20 \mu \mathrm{M})$, and BocD $(10 \mu \mathrm{M})$ for $6 \mathrm{~h}$, the TNF $\alpha$ mRNA level was determined by RT-PCR. (d) zVAD and BocD, but not QVD, promote autocrine production of TNF $\alpha$. L929 cells were treated as described in panel $\mathbf{c}$ in fresh medium for $8 \mathrm{~h}$, and the secreted TNF $\alpha$ level was measured by ELISA

function during zVAD-induced necroptosis. It is known that both canonical and non-canonical NF- $\kappa \mathrm{B}$ pathways are implicated in autocrine production of TNF $\alpha$ in cancer cells. ${ }^{26,28}$ In this study, we investigated whether NF- $\kappa$ B pathway is involved in $z V A D$-induced autocrine production of TNF $\alpha$. We first silenced $\mathrm{I}-\kappa \mathrm{B}$ kinase $(\mathrm{IKK} \beta)$ and $\mathrm{IKK} \alpha$, the two key upstream kinases of NF- $\kappa \mathrm{B}$. The IKK $\beta$ and IKK $\alpha$ knockdown efficiency was shown in Figure $3 a$. Disruption of the canonical NF- $\kappa \mathrm{B}$ pathway by targeting IKK $\beta$ markedly sensitized L929 cells to zVAD-induced cell death, whereas silencing the noncanonical pathway by targeting $\mathrm{IKK} \alpha$ did not significantly affect cell death (Figure $3 b$ ). We next disrupted the canonical and non-canonical NF- $\kappa$ B pathways by directly silencing their key components, RelA and RelB, respectively. The knockdown efficiency is shown in Figure 3c. Knockdown of RelA also greatly sensitized L929 cells to necroptosis induced by zVAD (Figure 3d), being consistent to the data from knockdown of IKK $\beta$ (Figure 3b). Finally, we found that knockdown of RelA or RelB failed to block the autocrine production of TNF $\alpha$ (Figure $3 e$ ). It is thus believed that neither the canonical nor the non-canonical NF- $\kappa$ B pathway contributes to zVADinduced TNF $\alpha$ transcription, and the canonical NF- $\kappa \mathrm{B}$ pathway acts as a prosurvival mechanism to ablate $z V A D$-induced cell death.

AP-1 activitation is required for ZVAD-induced autocrine production of TNF $\alpha$ and cell death. In addition to NF- $\kappa \mathrm{B}$, another important transcription factor, AP-1, has been implicated in TNF $\alpha$ transcription. ${ }^{32}$ We thus attempted to elucidate the possible role of AP-1 in zVAD-mediated autocrine production of $\mathrm{TNF} \alpha$ and subsequent necroptosis. As c-Jun is one of the essential components of AP-1, we first examined the effects of c-Jun knockdown on AP-1 activity, TNF $\alpha$ transcription, and cell death. The knockdown efficiency is shown in Figure 4a. Silencing of c-Jun significantly ablated AP-1 luciferase activity in the cells treated with ZVAD (Figure 4b) and reduced TNF $\alpha$ mRNA transcription (Figure 4c). As expected, knockdown of c-Jun dramatically suppressed zVAD-induced cell death in L929 cells (Figure 4d). Therefore, this set of data strongly implies that $\mathrm{AP}-1$ is responsible for $\mathrm{zVAD}$-stimulated TNF $\alpha$ transcription.

zVAD-induced AP-1 activation is mediated by JNK and ERK. Next, we sought to explore the upstream signaling pathways mediating $\mathrm{zVAD}$-induced $\mathrm{AP}-1$ activation, by focusing on mitogen-activated protein kinases (MAPKs). First, zVAD treatment was found to activate c-Jun (Figure 5a). Second, zVAD was able to enhance the phosphorylation of JNK and extracellular signal-regulated kinase (ERK), the two important MAPKs upstream of AP-1 (Figure $5 \mathrm{a}$ ). As TNF $\alpha$ is also known as a activator of MAPKs and C-Jun; ${ }^{33}$ it is thus possible that the activation of JNK, $E R K$, and c-Jun is triggered by autocrine production of $\operatorname{TNF} \alpha$, but not by zVAD per se. To exclude this possibility, we treated the cells with TNF $\alpha$-neutralizing antibody to block the secreted $T N F \alpha$ function and found that $z V A D$ was still capable of activating JNK, ERK, and c-Jun (Figure 5b), suggesting that zVAD-activated MAPKs is independent of autocrine production of TNF $\alpha$. To further test whether JNK and ERK are the upstream molecules mediating AP-1 activation upon zVAD treatment, we next used two chemical inhibitors, SP600125 (SP) and PD98059 (PD), to inhibit JNK and ERK activation, respectively. As shown in Figure $5 \mathrm{c}$, 
a

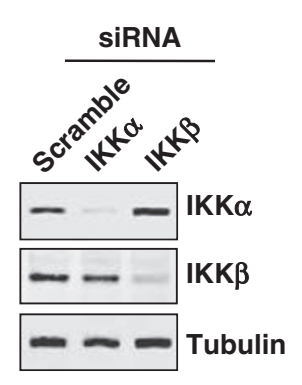

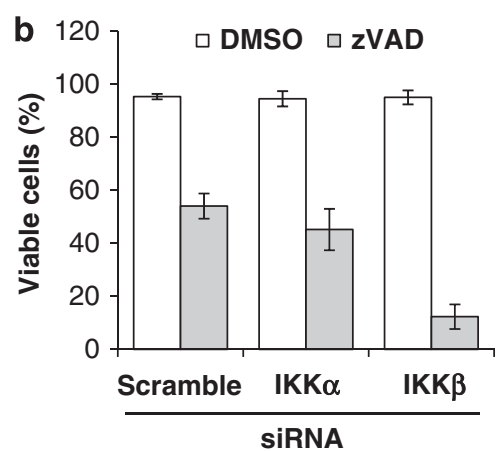

C

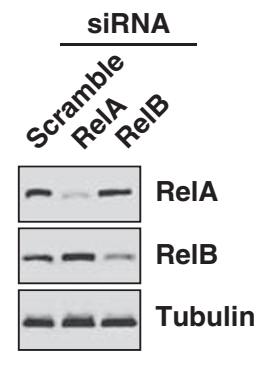

d

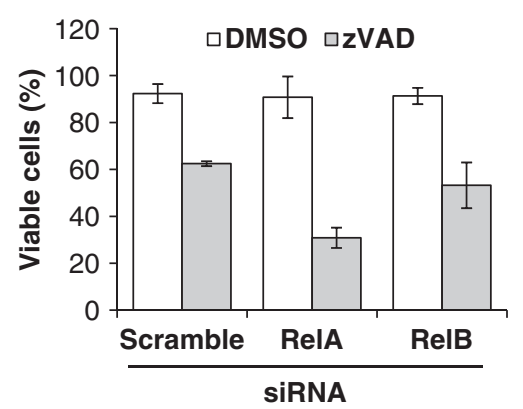

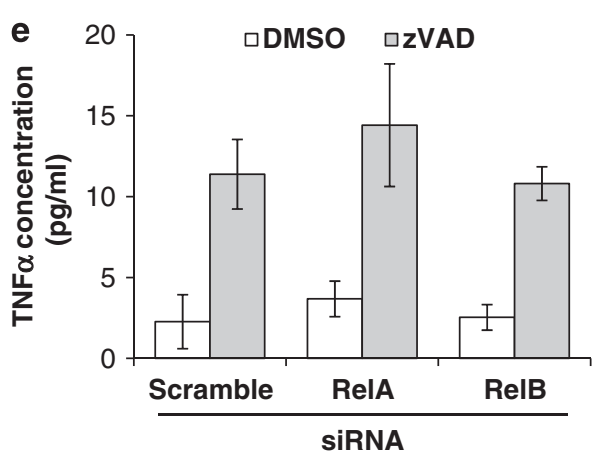

Figure 3 NF- $\kappa$ B pathway has a protective function during zVAD-fmk (zVAD)-induced necroptosis. (a) Knockdown of IKK $\alpha$ and IKK $\beta$ in L929 cells was performed as described in Materials and Methods section. (b) Effects of knockdown of IKK $\alpha$ and IKK $\beta$ on zVAD-induced cell death. After knockdown of IKK $\alpha$ and IKK $\beta$, cells were treated with zVAD $(10 \mu \mathrm{M})$ for $24 \mathrm{~h}$, and cell death was measured by the PI exclusion assay (data were presented as mean \pm S.D. from three independent experiments). (c) Knockdown of RelA and RelB in L929 cells was performed as described in Materials and Methods section. (d) Effects of knockdown of RelA and RelB on zVAD-induced cell death. Cells with knockdown of RelA and RelB were treated and the cell death was measured as described in panel $\mathbf{b}$. (e) Effects of knockdown of RelA and RelB on autocrine production of TNF $\alpha$. Cells with knockdown of RelA and RelB were treated with DMSO or ZVAD $(10 \mu \mathrm{M})$ for $8 \mathrm{~h}$, secreted TNF $\alpha$ was determined by ELISA

these two inhibitors almost completely abrogated zVADinduced phosphorylation of JNK and ERK, as well as that of c-Jun. As a result, they blocked zVAD-induced AP-1 activation as determined by the AP-1 luciferase assay (Figure $5 \mathrm{~d}$ ). As expected, these inhibitors dramatically suppressed the autocrine production of TNF $\alpha$ (Figure 5e) and eventually offered perfect protection against $z V A D$-induced necroptosis in L929 cells (Figure 5f). Therefore, data from this part of the study clearly demonstrate that the MAPKs-mediated AP-1 activation is required for $z V A D$-induced autocrine production of $\mathrm{TNF} \alpha$ and subsequent necroptosis.

PKC has a critical function in zVAD-mediated MAPKs-AP1 activation, autocrine production of TNF $\alpha$, and cell death. After establishing the role of MAPKs (JNK and ERK) in zVAD-induced TNF $\alpha$ transcription, here we sought to find the upstream mechanism mediating zVAD-induced MAPKs activation. It has been well established that PKC is one of the important signals upstream of MAPKs. ${ }^{34}$ Therefore, we examined whether zVAD is able to activate MAPKs by PKC. First, zVAD was found to evidently activate PKC, similar to the effect of 12-O-tetradecanoylphorbol-13acetate (TPA), as determined by phosphorylation of the total PKC substrate (Figure 6a). A PKC inhibitor (PKCi, bisindolylmaleimide I) was able to completely inhibit both reactions. Importantly, TPA enhanced, whereas PKCi effectively suppressed, zVAD-induced phosphorylation of
JNK, ERK, and c-Jun (Figure 6b), suggesting that PKC acts upstream of JNK and ERK, leading to AP-1 activation. Consistently, TPA was found to promote TNF $\alpha$ transcription and secretion (Figure $6 \mathrm{c}$ and $\mathrm{d}$ ). Moreover, TPA further enhanced, whereas PKCi almost completely blocked, zVADinduced TNF $\alpha$ autocrine production (Figure $6 \mathrm{c}$ and $\mathrm{d}$ ). As expected, TPA markedly increased, whereas PKCi perfectly protected against, zVAD-induced cell death. Interestingly, TPA and PKCi modulated exogenously administered TNF $\alpha$ induced necroptosis in an opposite pattern to their effects on zVAD-induced necroptosis (Figure 6e). These results suggest that activation of PKC can enhance $Z V A D$-induced necroptosis by promoting autocrine production of $\mathrm{TNF} \alpha$, without affecting the downstream TNF $\alpha$ signaling pathways.

To further understand the involvement of PKC in zVADinduced necroptosis as demonstrated above, we compared the effects of different pan-caspase inhibitors on PKC activation. As anticipated, zVAD-fmk and BocD-fmk, but not QVD-oph, were capable of activating PKC, as well as JNK, ERK, and c-Jun (Figure 7a). This result prompted us to test whether activation of PKC would affect the effect of QVD-oph on L929 cells. Interestingly, TPA indeed effectively turned QVD-oph into a cell killer (Figure 7b), while it has no effect on DEVD-cho (caspase 3 inhibitor) (Figure 7b), indicating that inhibition of certain caspases by QVD-oph, but not by DEVD-cho, is critical for such cell death. Similarly, TPA was also effective for induction of necroptosis in cells with 

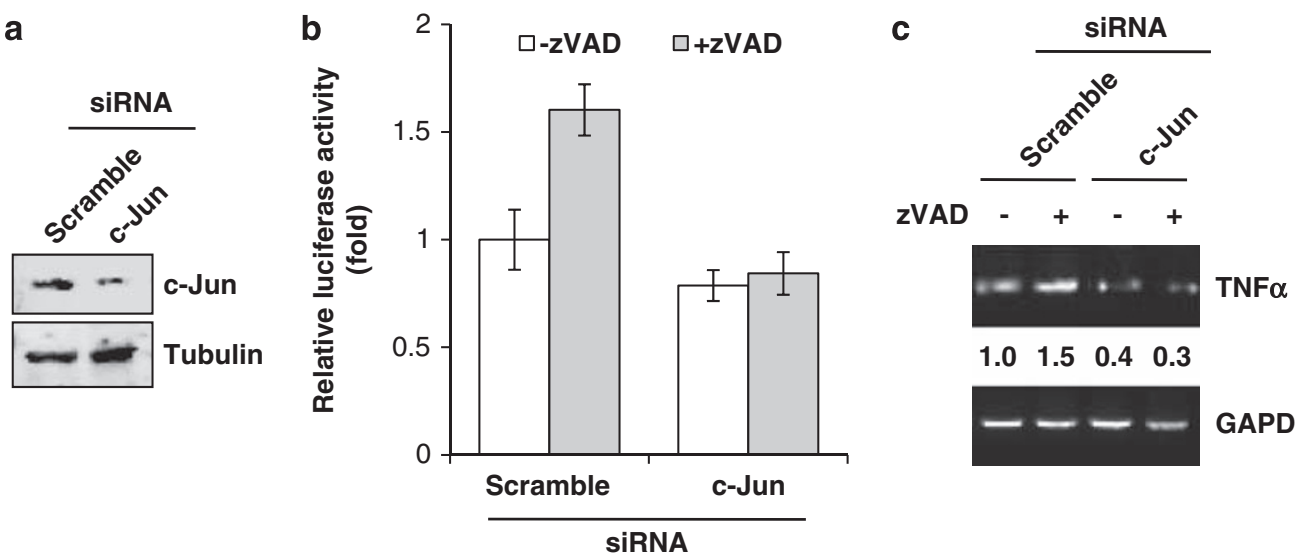

$\begin{array}{llll}1.0 & 1.5 & 0.4 & 0.3\end{array}$
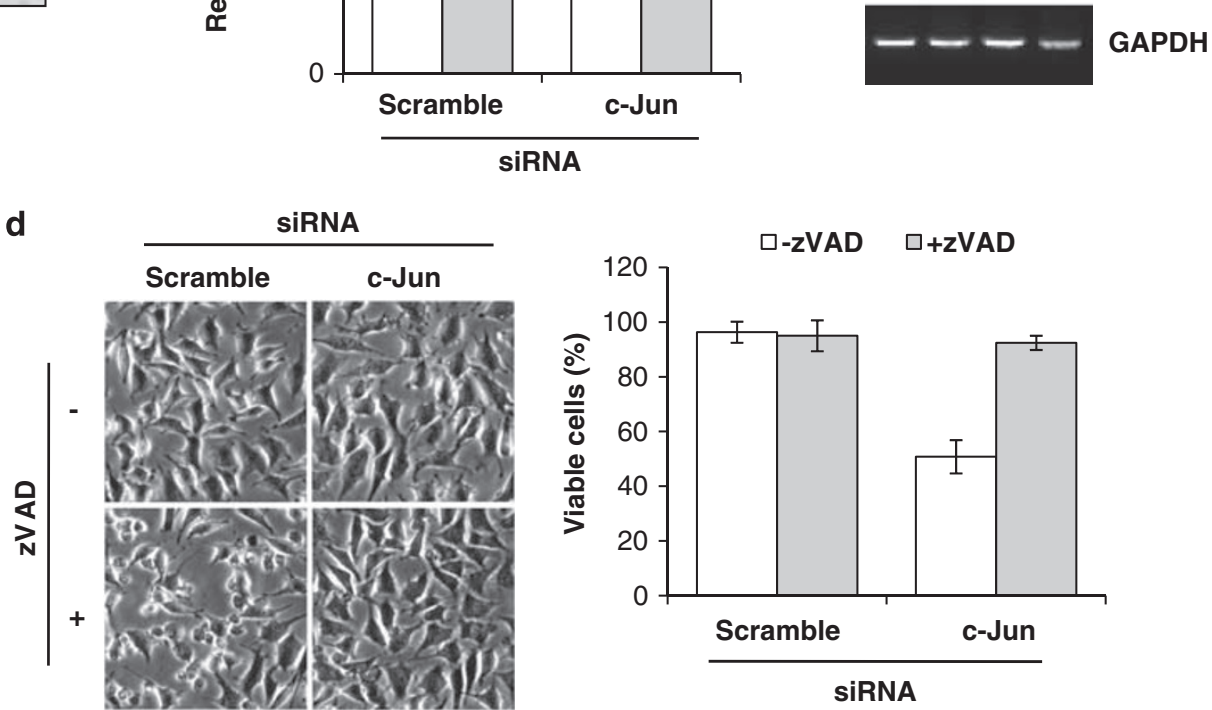

Figure 4 AP-1 activity is required for ZVAD-fmk (ZVAD)-induced TNF $\alpha$ production and necroptosis. (a) Knockdown of c-Jun was performed as described in Materials and Methods section. (b) Knockdown of c-Jun inhibits zVAD-induced AP-1 luciferase activity. Cells with knockdown of c-Jun were transfected with the AP-1 and Renilla luciferase vectors for $24 \mathrm{~h}$ and then were treated with $\mathrm{ZVAD}(10 \mu \mathrm{M})$ for additional $10 \mathrm{~h}$. The AP-1 luciferase activity was measured as described in Materials and Methods section. (c) Knockdown of c-Jun abolishes ZVAD-induced TNF $\alpha$ transcription. Knockdown of c-Jun was performed as described in panel a, followed by treatment with zVAD (10 $\mu$ M) for $6 \mathrm{~h}$. TNF $\alpha$ mRNA level was determined by RT-PCR. (d) Knockdown of c-Jun blocks ZVAD-induced cell death. Knockdown of c-Jun was performed as described in panel a, followed by treatment with $\mathrm{ZVAD}(10 \mu \mathrm{M})$ for $24 \mathrm{~h}$. Cell death was determined as described in Figure $1 \mathrm{a}$

knockdown of caspase 8 (Figure 7c), whereas knockdown of caspase 8 per se is not cytotoxic (Supplementary Figure S1). Such observations thus suggest that both autocrine production of TNF $\alpha$ and inhibition of the caspase cascade are required for necroptosis induced by zVAD-fmk and BocD-fmk.

\section{Discussion}

In recent years, necrotic cell death has been increasingly appreciated as an important form of PCD. In contrast to apoptosis, the molecular mechanisms underlying necrosis is much less understood. Necrosis usually occurs in cells when the apoptosis machinery is suppressed or absent. zVADinduced necrotic cell death is among several necrosis models established so far. In this study, we identified autocrine production of TNF $\alpha$ as the missing pro-death signal in ZVADinduced necrotic cell death or necroptosis. Such results are indeed consistent with a recent report in which TNFR1 and autocrine production of TNF $\alpha$ were found to be crucial for zVAD-induced necrosis in L929 cells. ${ }^{30}$ It is known that endogenously produced TNF $\alpha$ can be secreted into the extracellular environments or exists as a membrane-bound form, both of which are able to trigger downstream signaling, leading to cell death. ${ }^{35}$ It is to be noted that our data suggest that ZVAD-fmk-induced necroptosis in L929 cells is predominantly executed by the secreted soluble TNF $\alpha$, on the basis of the following observations: (i) the TNF $\alpha$-neutralizing antibody, which can only neutralize the soluble TNF $\alpha$ in medium, attenuated zVAD-fmk-induced cell death (Supplementary Figure S3b) and (ii) blocking the soluble $\mathrm{TNF} \alpha$ by the DN-TNF protein offered perfect protection against zVADfmk-induced cell death (Supplementary Figure S3c).

The major aim of this study is to understand the molecular mechanisms underlying zVAD-induced autocrine production of TNF $\alpha$. It is known that the TNF $\alpha$ promoter region contains both NF- $\kappa$ B and AP-1 responsive elements. ${ }^{36}$ In cancer cells treated with the IAP antagonists, autocrine TNF $\alpha$ is produced by both the canonical and non-canonical NF- $\kappa$ B pathways. ${ }^{26,28}$ In this study, we show that $z V A D$ mainly uses the AP-1 pathway, but not the NF- $\kappa$ B pathway, to promote TNF $\alpha$ transcription (Figures 3 and 4). It is to be noted that such a notion is also supported by the finding in which, by using genome-wide RNAi library screening, Jun, but not NF- $\kappa$ B components, was identified as one of the critical functions involved in zVAD-induced necrosis. ${ }^{30}$ Moreover, we demonstrate that $Z$ VAD-induced AP-1 activation in L929 cells is mediated by the activation of MAPKs including JNK and ERK (Figure 5). These data are indeed consistent with recent 


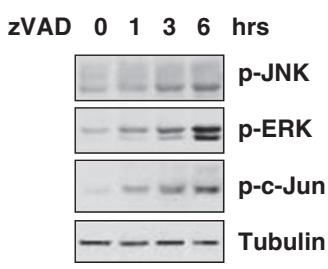

b

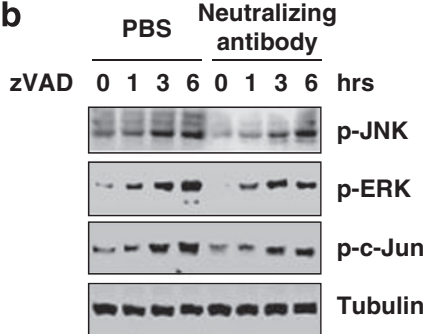

C

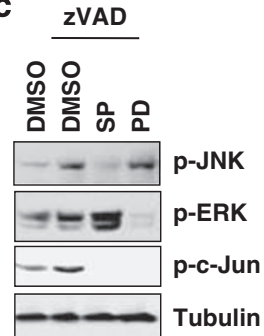

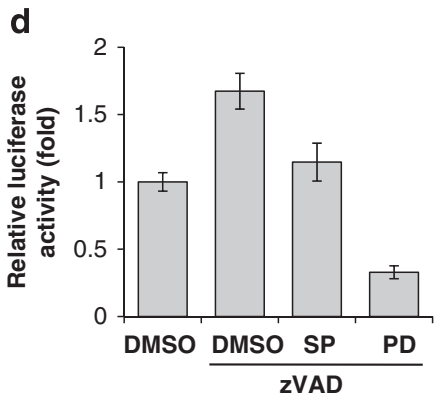

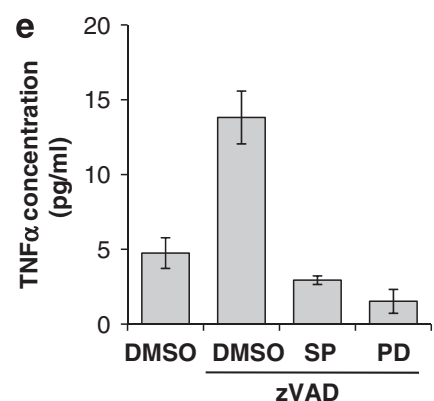

f

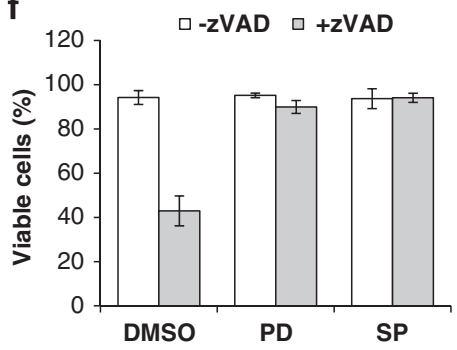

Figure 5 zVAD-fmk(zVAD)-induced AP-1 activation is mediated by JNK and ERK. (a) zVAD activates JNK, ERK, and c-Jun. L929 cells were treated with zVAD (10 $\mu$ M) for up to $6 \mathrm{~h}$. Cell lysate was subjected to western blotting. (b) zVAD activates JNK, ERK, and c-Jun in the presence of TNF $\alpha$-neutralizing antibody. Cells were pretreated with TNF $\alpha$-neutralizing antibody $(2.0 \mu \mathrm{g} / \mathrm{ml})$ for $1 \mathrm{~h}$, followed by treatment with zVAD as described in panel a, cell lysate was subjected to western blotting. (c) MAPKs inhibitors suppress zVAD-induced c-Jun phosphorylation. L929 cells were treated with ZVAD $(10 \mu \mathrm{M})$ with or without the presence of SP600125 (SP, $20 \mu \mathrm{M})$ or PD98059 (PD, $20 \mu \mathrm{M})$ for $6 \mathrm{~h}$, and cell lysate was subjected to immunoblotting. (d) MAPKs inhibitors suppress zVAD-stimulated AP-1 luciferase activity. L929 cells were transfected with luciferase vectors for $24 \mathrm{~h}$, and then were treated as described in panel $\mathbf{c}$ for $10 \mathrm{~h}$, the AP-1 activity was measured by the luciferase assay. (e) MAPKs inhibitors block zVAD-induced autocrine production of TNF $\alpha$. L929 cells were incubated in fresh medium and were treated as described in panel $\mathbf{c}$ for $8 \mathrm{~h}$, the TNF $\alpha$ protein level in the culturing medium was determined by ELISA. (f) MAPKs inhibitors protect ZVAD-induced cell death. L929 cells were treated as described in panel $\mathbf{c}$ for $24 \mathrm{~h}$, and cell death was measured as described in Figure $3 b$

reports that TNF $\alpha$ expression was regulated by $\mathrm{JNK}^{32}$ or ERK. ${ }^{37}$ Therefore, it appears that the transcriptional machinery for $\mathrm{TNF} \alpha$ expression is cell type and stimulus specific.

One important finding in this study is that PKC acts upstream of MAPKs to promote autocrine production of TNF $\alpha$ in response to $z V A D$. The PKC family is an important group of proteins with diverse functions in many cellular processes such as cell proliferation, differentiation, and cell death. ${ }^{38}$ Among the three pan-caspase inhibitors tested in this study (zVAD-fmk, BocD-fmk, and QVD-oph), their effects on PKC activation, autocrine production of $\mathrm{TNF} \alpha$, and induction of cell death are highly correlated (Figures 1a, 2c, d, and 7a). Moreover, when combining with caspase inhibition, the typical PKC activator, TPA, was found to induce necroptosis in L929 cells (Figure $7 \mathrm{~b}$ and $\mathrm{c}$ ). Among the three groups of PKC, TPA is able to activate both the conventional $(\alpha, \beta$, and $\gamma)$ and novel $(\delta, \varepsilon, \theta$, and $\eta)$ isoforms of PKC. ${ }^{39}$ Therefore, future work should include the identification of the exact isoforms of PKC involved in zVAD-induced autocrine production of TNF $\alpha$ and cell death. Another important and intriguing question would be how zVAD activates PKC. It appears that the activation of $P K C$ is not related to caspase inhibition as QVD-oph fails to activate PKC. On the other hand, zVAD-fmk and BocD-fmk have been reported to possess nonspecific inhibitory effect toward other proteases such as cathepsins, while QVD-oph does not. ${ }^{22}$ It is thus possible that PKC activation might be due to the off-target effect of zVAD-fmk and BocD-fmk.

Although $z V A D$ has been shown in this study to promote $\mathrm{TNF} \alpha$ transcription and production, the autocrine level is still very low (around $10 \mathrm{pg} / \mathrm{ml}$ ) (Figure 2b). Exogenous TNF $\alpha$ of such a concentration was found not cytotoxic (data not shown). Remarkably, when combining with zVAD, exogenous TNF $\alpha$ could induce necroptosis in L929 cells with a much faster kinetics and at a much lower concentration (data not shown). Therefore, it is believed that ZVAD performs a dual function to induce necroptosis in L929 cells: (i) to promote autocrine production of TNF $\alpha$, and (ii) to sensitize L929 cells to TNF $\alpha$ induced necroptosis, most probably by suppression of the caspase cascade. At present, there is some evidence linking caspase suppression with promotion of necroptosis, on the basis of an earlier report that RIP1, the key kinase in TNF $\alpha$ mediated necroptosis, is cleaved by caspase $8 .{ }^{17}$ This notion is also supported and strengthened by the following observations from this study: (i) although TPA alone and QVD-oph alone were not cytotoxic, combined treatment of TPA and QVD-oph was able to kill the cells efficiently (Figure 7b); and (ii) TPA alone was capable of inducing necroptosis when caspase 8 is silenced (Figure 7c). Thus far, the detailed mechanism underlying this sensitization effect requires further investigations.

Targeting caspase has been developed as a therapeutic approach to inhibit pathological apoptosis in vivo. However, the success of antiapoptotic therapies has been limited in mammalian cells and one possible reason is that the cells may undergo necrosis in the absence of apoptotic pathway. 5,15 Such a hypothesis is underscored by two very recent studies: the programmed necrosis in vivo was shown to implicate in the defense against vaccinia virus infection, ${ }^{13}$ and cerulein-induced acute pancreatitis is resulted from massive 

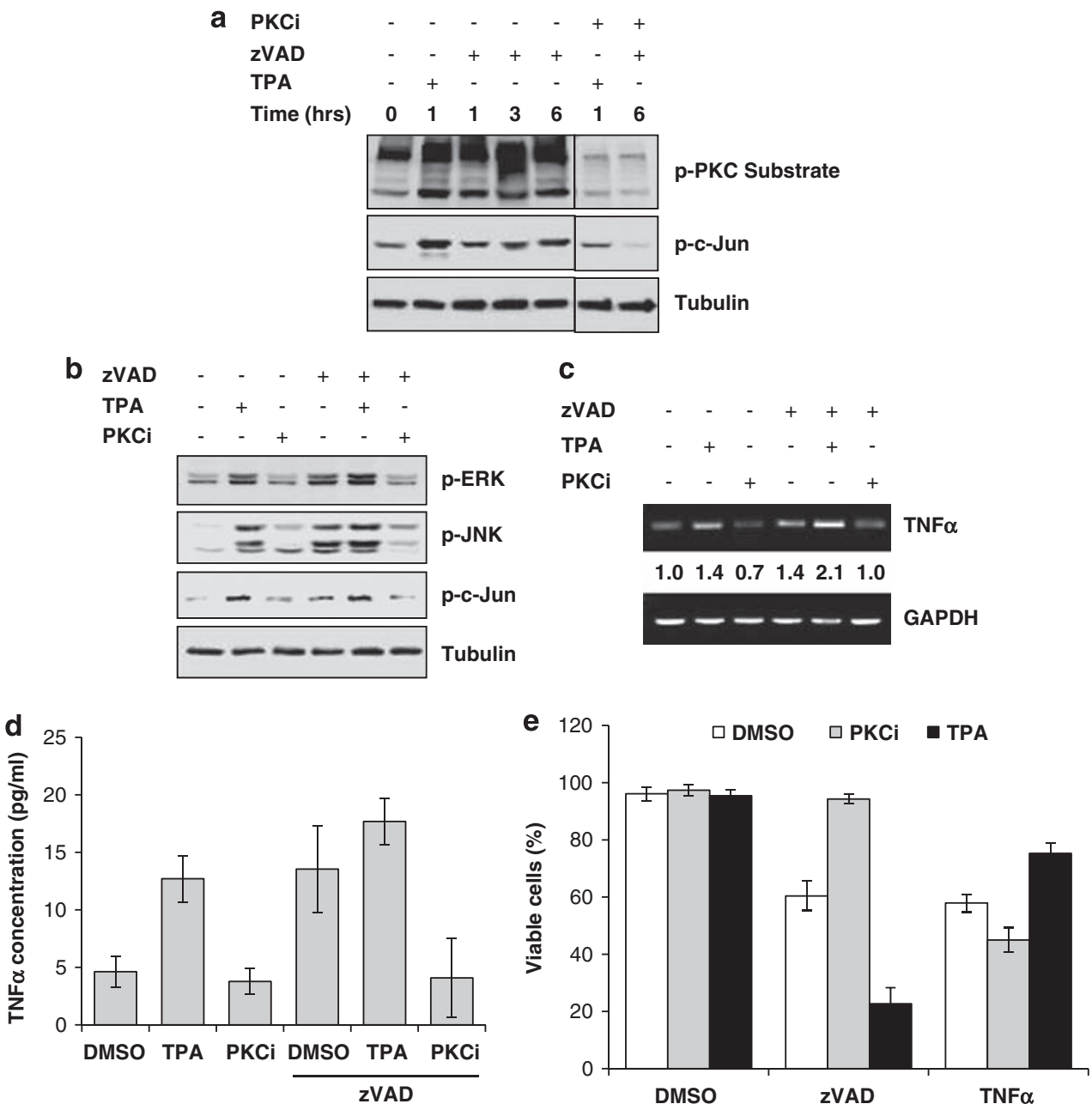

Figure 6 PKC has a critical function in zVAD-fmk (zVAD)-induced JNK, ERK, andAP-1 activation, and consequent TNF $\alpha$ production and necroptosis. (a) zVAD activates PKC. L929 cells were treated with $\mathrm{ZVAD}(10 \mu \mathrm{M})$ for up to $6 \mathrm{~h}$, with or without the presence of PKCi $(1 \mu \mathrm{M})$. TPA $(80 \mathrm{nM} \times 1 \mathrm{~h})$ was used as a positive control. Activation of PKC was determined by the phosphorylation of PKC substrates using immunoblotting. (b) Effects of TPA and PKCi on zVAD-induced activation of JNK and ERK. L929 cells were treated with $\mathrm{ZVAD}(10 \mu \mathrm{M})$, TPA $(80 \mathrm{nM})$, or PKCi $(1 \mu \mathrm{M})$ as indicated in the figure for $6 \mathrm{~h}$, and cell lysate was subjected to immunoblotting. (c) Effects of TPA and PKCi on zVAD-induced TNF $\alpha$ transcription. Cells were treated as described in panel $\mathbf{b}$ for $6 \mathrm{~h}$, TNF $\alpha$ mRNA level was determined by RT-PCR. (d) PKC activation contributes to ZVAD-induced autocrine production of TNF $\alpha$. L929 cells were treated as described in panel $\mathbf{b}$ for $8 \mathrm{~h}$, concentration of the TNF $\alpha$ protein level in the medium was determined by ELISA. (e) PKC activation enhances zVAD-induced cell death but suppresses TNF $\alpha$-induced cell death. L929 cells were treated with $\mathrm{ZVAD}(10 \mu \mathrm{M} \times 24 \mathrm{~h})$ or TNF $\alpha$ $(1 \mathrm{ng} / \mathrm{ml} \times 8 \mathrm{~h})$ with or without the presence of PKCi $(1 \mu \mathrm{M})$ or TPA $(80 \mathrm{nM})$. Cell death was determined as described in Figure $3 \mathrm{~b}$

necrosis in vivo. ${ }^{8}$ Interestingly, in both models, the necrosis was triggered by endogenous TNF $\alpha$. As a potent pan-caspase inhibitor, zVAD has been applied to various animal models to suppress the apoptotic responses. Recently, ZVAD was reported to improve the therapeutic outcomes of radiation on tumor xenograft. ${ }^{40}$ It remains to be further determined whether the observed therapeutic effect of ZVAD in vivo is due to caspase inhibition and suppression of apoptosis or due to promotion of autocrine production of $\mathrm{TNF} \alpha$ and induction of necroptosis.

Taken together, data from this study suggest that a group of caspase inhibitors represented by zVAD are capable of inducing programmed necrosis or necroptosis by the following two orchestrated pathways: (i) promotion of autocrine production of TNF $\alpha$ by PKC-MAPKs-AP-1 signaling pathway, and (ii) inhibition of the caspase cascade, as illustrated in Figure $7 \mathrm{~d}$. It is of interest to further examine whether $\mathrm{ZVAD}$ or other caspase inhibitors possess similar effects on other cell types, especially in human cancer cells.

\section{Materials and Methods}

Reagents and antibodies. The zVAD-fmk and DEVD-cho were purchased from BioMol (Plymouth Meeting, PA, USA). The BocD-fmk, QVD-oph, IETD-fmk, IETD-oph, and bisindolylmaleimide I (PKCi) were purchased from Calbiochem (San Diego, CA, USA). The antibodies against caspase 8 (4927), caspase 3 (9662), PARP-1 (9542), c-Jun (9162), RelB (4922), phosphor-ERK (thr202/tyr204) (9101), phosphor-c-Jun (ser73) (9164), and phosphor-PKC substrate (2261) were obtained from Cell Signaling (Danvers, MA, USA). The anti-phosphor-JNK (Thr183/Tyr185) (44-682G) was obtained from Biosource (Camarillo, CA, USA). The anti-RelA (SC8008) and anti-IKK $\alpha$ (SC-7218) antibodies were from Santa Cruz (Santa Cruz, CA, USA). The anti-RIP3 (2283) antibody was obtained from ProSci (San Diego, CA, USA). The anti-IKK $\beta$ (05-535) antibody was from Upstate (New York City, NY, USA). The TNF $\alpha$-neutralizing antibody (AF-410-NA), and TNFR1-blocking antibody (AF-425-PB), mouse TNF $\alpha$ and TRAIL were purchased from R\&D (Minneapolis, MN, USA). The TPA, ActD, CHX, SP600125, PD98059, and anti- $\alpha$-tubulin antibody 


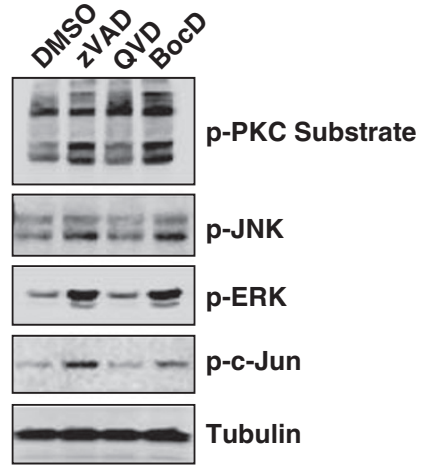

b

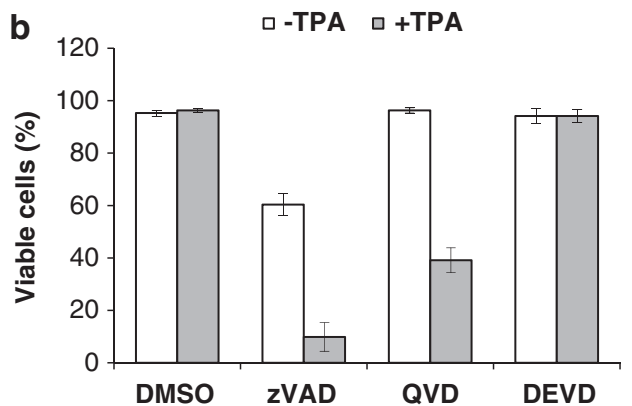

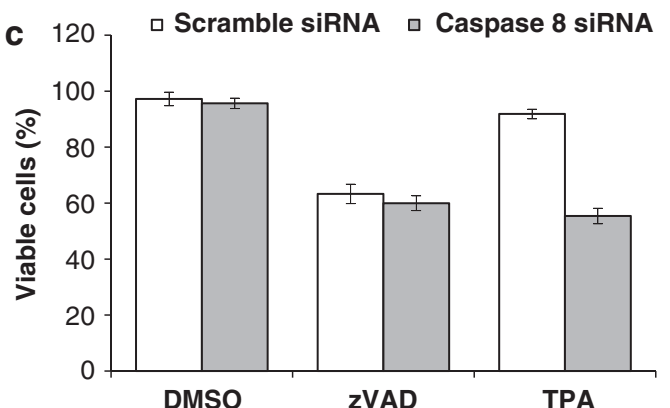

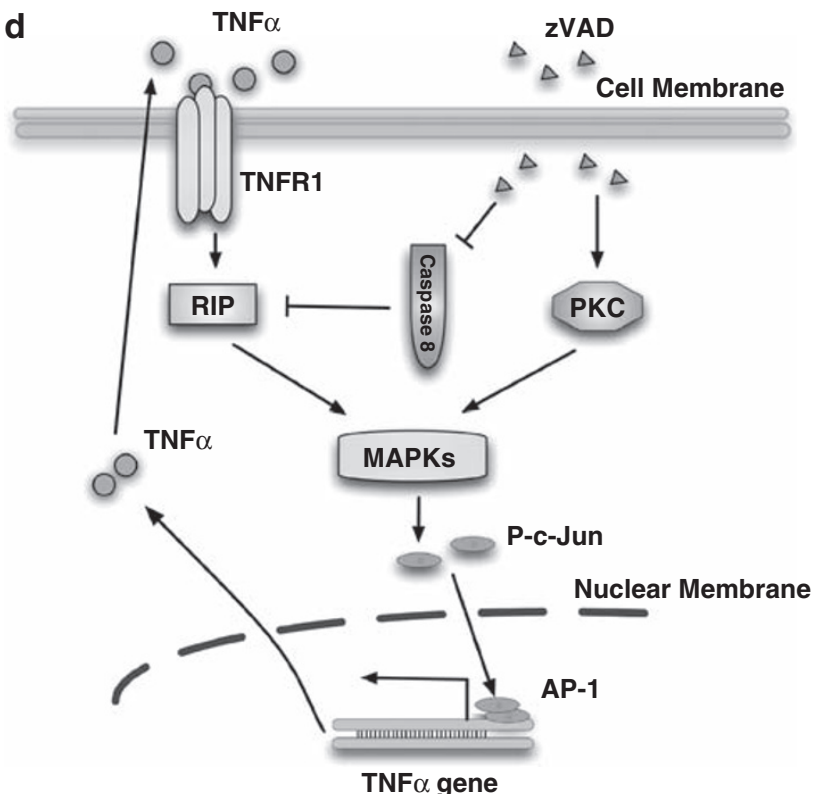

Figure 7 TPA combining with caspase 8 inhibition induces necroptosis in L929 cells. (a) zVAD-fmk (zVAD) and BocD-fmk (BocD), but not QVD-oph (QVD), activate the PKC-MAPKs-AP-1 signaling pathway. L929 cells were treated with ZVAD $(10 \mu \mathrm{M})$, QVD $(20 \mu \mathrm{M})$, or BocD $(10 \mu \mathrm{M})$ for $6 \mathrm{~h}$, and cell lysate was subjected to immunoblotting. (b) QVD, when combining with TPA, induces cell death. L929 cells were treated with zVAD $(10 \mu \mathrm{M}), \mathrm{QVD}(20 \mu \mathrm{M})$, or DEVD-cho (DEVD, $100 \mu \mathrm{M})$ with or without the presence of TPA $(80 \mathrm{nM})$ for $24 \mathrm{~h}$, and cell death was quantified as described in Figure 3b. (c) TPA induces cell death in caspase 8 knockdown cells. L929 cells with knockdown of caspase 8, were treated with TPA $(80 \mathrm{nM})$ or ZVAD $(10 \mu \mathrm{M})$ for $24 \mathrm{~h}$, cell death was determined as described in Figure $3 \mathrm{~b}$. (d) lllustration of the signaling pathways for zVADinduced necroptosis. Both promotion of autocrine production of TNF $\alpha$ by the PKC-MAPKs-AP-1 signaling pathway and suppression of caspase activation to stabilize RIP1 are required for necroptosis induced by ZVAD

were purchased from Sigma-Aldrich (St Louis, MO, USA). XENP1595, the DN-TNF against soluble TNF $\alpha$ was kindly provided by Dr. Szymkowski DE (Xencor).

Cell culture. L929 cells were maintained in Dulbecco's modified Eagle's medium (Sigma-Aldrich) containing 10\% fetal bovine serum (HyClone, Cramlington, UK) and 1\% penicilin-streptomycin (Invitrogen, Carlsbad, CA, USA) in a $5 \% \mathrm{CO}_{2}$ atmosphere at $37^{\circ} \mathrm{C}$.
Detection of cell death. The cell death was detected by (i) morphological changes examined under a microscope and (ii) the propidium iodide (PI) exclusion assay coupled with flow cytometry to quantify the percentage of viable cells, as described previously.20 Briefly, cells were trypsinized and collected after designated treatments and were resuspended in PBS containing PI for incubation at $37^{\circ} \mathrm{C}$ for $10 \mathrm{~min}$. Ten thousand cells from each sample were 
scanned and analyzed with FACSCalibur flow cytometer and CellQuest software (BD Biosciences, San Jose, CA, USA).

Small interfering RNA. The nonspecific small interfering RNA (siRNA) oligonucleotides and siRNA oligonucleotides targeting mouse caspase 8, FADD, RIP3, c-Jun, IKK $\alpha$, IKK $\beta$, RelA, and RelB (ON-TARGETplus SMARTpool) were all obtained from Dharmacon (Layfayette, CO, USA). All siRNA were transfected into L929 cells using the DharmaFECT 4 Transfection Reagent according to manufacturer's protocol.

Transfection and luciferase reporter assay. For CrmA transfection, cells grown in 24-well plates were transfected with CrmA and EGFP plasmids $(10: 1)$ using Lipofectamine and Plus reagent (Invitrogen) according to manufacturer's instruction. For AP-1 luciferase assay, cells grown in 24-well plates first were transfected with AP-1-Luc and Renilla plasmids (100:1) using Lipofectamine and Plus reagent (Invitrogen) according to manufacturer's instruction. Twenty-four hours after transfection, cells were treated as indicated in each figure legend. The AP-1 luciferase activity was measured using a DualLuciferase(R) Reporter Assay kit (Promega, Madison, WI, USA) on a Glomax 96 Microplate Luminometer (Promega) according to manufacturer's protocol.

Reverse transcription-PCR. RNA was extracted using an RNeasy kit (Qiagen, Germantown, MD, USA). One microgram of total RNA from each sample was used as a template for CDNA synthesis by a QuantiTect Reverse Transcriptase Kit (Qiagen). An equal volume of cDNA product was used in the PCR performed using the TopTaq Master Mix Kit (Qiagen). The mouse TNF $\alpha$ and GAPDH primers were purchased from R\&D. The PCR reaction conditions were set according to the protocol coming with primers (R\&D). The PCR products were resolved using an agarose gel containing GelRed Nucleic Acid Gel Stain (Biotium, Hayward, CA, USA), and exposed on a Kodak Image Station 440CF (Kodak, Rochester, NY, USA). The band density was quantified using ImageJ image processing program (NIH, Bethesda, $M D, U S A)$ and normalized to that of the control group.

Measurement of autocrine production of TNF $\alpha$ in culturing medium by ELISA. Cells grown in a 10-cm dish were washed with PBS twice, then were incubated in fresh medium and treated as described in the figure legends. The culture medium was collected and the concentration of TNF $\alpha$ was determined by a Mouse TNF-alpha/TNFSF1A Quantikine ELISA Kit (R\&D) following the instruction from the manufacturer.

Western blotting. Cells were lysed in M2 lysis buffer: $20 \mathrm{mM}$ Tris at $\mathrm{pH} 7,0.5 \%$ NP-40, $250 \mathrm{mM} \mathrm{NaCl}, 3 \mathrm{mM}$ EDTA, $3 \mathrm{mM}$ EGTA, 2 mM dithiothreitol, phosphatase inhibitor cocktail (Pierce, Rockford, IL, USA) and protease inhibitor cocktail (Roche, Indianapolis, IN, USA). Equal amount of protein was fractionated on SDS-PAGE and transferred onto PVDF membrane (Bio-Rad, Hercules, CA, USA). After blocking with $5 \%$ non-fat milk, the membrane was probed with designated first antibodies and second antibodies (Pierce) and developed with enhanced chemiluminescence reagents (Pierce) and visualized on a Kodak Image Station 440CF (Kodak).

\section{Conflict of interest}

The authors declare no conflict of interest.

Acknowledgements. We thank Dr. Szymkowski for providing reagent. Y-T Wu is supported by an NUS research scholarship. This study is supported by grants from the NUS University Research Council (URC) and Singapore Biomedical Research Council (BMRC) to H-M Shen. This work is also supported in part by the Toxicology Program under the Life Science Institute, NUS.

1. Kroemer G, Galluzzi L, Vandenabeele P, Abrams J, Alnemri ES, Baehrecke EH et al. Classification of cell death: recommendations of the Nomenclature Committee on Cell Death 2009. Cell Death Differ 2009; 16: 3-11.

2. White E. Autophagic cell death unraveled: pharmacological inhibition of apoptosis and autophagy enables necrosis. Autophagy 2008; 4: 399-401.

3. Levine B, Yuan J. Autophagy in cell death: an innocent convict? J Clin Invest 2005; 115 : 2679-2688.

4. Zong WX, Thompson CB. Necrotic death as a cell fate. Genes Dev 2006; 20: 1-15.
5. Degterev A, Yuan J. Expansion and evolution of cell death programmes. Nat Rev Mol Cell Biol 2008; 9: 378-390.

6. Micheau O, Tschopp J. Induction of TNF receptor I-mediated apoptosis via two sequential signaling complexes. Cell 2003; 114: 181-190.

7. Vercammen D, Vandenabeele P, Beyaert R, Declercq W, Fiers W. Tumour necrosis factor-induced necrosis versus anti-Fas-induced apoptosis in L929 cells. Cytokine 1997; 9: 801-808.

8. He S, Wang L, Miao L, Wang T, Du F, Zhao L et al. Receptor interacting protein kinase-3 determines cellular necrotic response to TNF-alpha. Cell 2009; 137: 1100-1111.

9. Holler N, Zaru R, Micheau O, Thome M, Attinger A, Valitutti S et al. Fas triggers an alternative, caspase-8-independent cell death pathway using the kinase RIP as effector molecule. Nat Immunol 2000; 1: 489-495.

10. Lin Y, Choksi S, Shen HM, Yang QF, Hur GM, Kim YS et al. Tumor necrosis factor-induced nonapoptotic cell death requires receptor-interacting protein-mediated cellular reactive oxygen species accumulation. J Biol Chem 2004; 279: 10822-10828.

11. Festjens N, Vanden Berghe T, Cornelis S, Vandenabeele P. RIP1, a kinase on the crossroads of a cell's decision to live or die. Cell Death Differ 2007; 14: 400-410.

12. Kim YS, Morgan MJ, Choksi S, Liu ZG. TNF-induced activation of the Nox1 NADPH oxidase and its role in the induction of necrotic cell death. Mol Cell 2007; 26: 675-687.

13. Cho YS, Challa S, Moquin D, Genga R, Ray TD, Guildford M et al. Phosphorylation-driven assembly of the RIP1-RIP3 complex regulates programmed necrosis and virus-induced inflammation. Cell 2009; 137: 1112-1123.

14. Zhang DW, Shao J, Lin J, Zhang N, Lu BJ, Lin SC et al. RIP3, an energy metabolism regulator that switches TNF-induced cell death from apoptosis to necrosis. Science 2009; 325: 332-336.

15. Vandenabeele $P$, Vanden Berghe T, Festjens N. Caspase inhibitors promote alternative cell death pathways. Sci STKE 2006; 2006: pe44.

16. Vercammen D, Beyaert R, Denecker G, Goossens V, Van Loo G, Declercq W et al. Inhibition of caspases increases the sensitivity of $L 929$ cells to necrosis mediated by tumor necrosis factor. J Exp Med 1998; 187: 1477-1485.

17. Lin Y, Devin A, Rodriguez Y, Liu ZG. Cleavage of the death domain kinase RIP by caspase-8 prompts TNF-induced apoptosis. Genes Dev 1999; 13: 2514-2526.

18. Van Noorden CJ. The history of Z-VAD-FMK, a tool for understanding the significance of caspase inhibition. Acta Histochem 2001; 103: 241-251.

19. Yu L, Alva A, Su H, Dutt P, Freundt E, Welsh $S$ et al. Regulation of an ATG7-beclin 1 program of autophagic cell death by caspase-8. Science 2004; 304: 1500-1502.

20. Wu YT, Tan HL, Huang Q, Kim YS, Pan N, Ong WY et al. Autophagy plays a protective role during zVAD-induced necrotic cell death. Autophagy 2008; 4: $457-466$.

21. Wu YT, Tan HL, Huang Q, Ong CN, Shen HM. Activation of the PI3K-Akt-mTOR signaling pathway promotes necrotic cell death via suppression of autophagy. Autophagy 2009; 5: 824-834.

22. Chauvier D, Ankri S, Charriaut-Marlangue C, Casimir R, Jacotot E. Broad-spectrum caspase inhibitors: from myth to reality? Cell Death Differ 2007; 14: 387-391.

23. Ray CA, Black RA, Kronheim SR, Greenstreet TA, Sleath PR, Salvesen GS et al. Viral inhibition of inflammation: cowpox virus encodes an inhibitor of the interleukin-1 beta converting enzyme. Cell 1992; 69: 597-604.

24. Degterev A, Hitomi J, Germscheid M, Ch'en IL, Korkina O, Teng X et al. Identification of RIP1 kinase as a specific cellular target of necrostatins. Nat Chem Biol 2008; 4: 313-321.

25. Vercammen D, Vandenabeele P, Declercq W, Van de Craen M, Grooten J, Fiers W. Cytotoxicity in L929 murine fibrosarcoma cells after triggering of transfected human p75 tumour necrosis factor (TNF) receptor is mediated by endogenous murine TNF. Cytokine 1995; 7: 463-470.

26. Vince JE, Wong WW, Khan N, Feltham R, Chau D, Ahmed AU et al. IAP antagonists target clAP1 to induce TNFalpha-dependent apoptosis. Cell 2007; 131: 682-693.

27. Petersen SL, Wang L, Yalcin-Chin A, Li L, Peyton M, Minna J et al. Autocrine TNFalpha signaling renders human cancer cells susceptible to Smac-mimetic-induced apoptosis. Cancer Cell 2007; 12: 445-456.

28. Varfolomeev E, Blankenship JW, Wayson SM, Fedorova AV, Kayagaki N, Garg P et al. IAP antagonists induce autoubiquitination of c-IAPs, NF-kappaB activation, and TNFalphadependent apoptosis. Cell 2007; 131: 669-681.

29. Zalevsky J, Secher T, Ezhevsky SA, Janot L, Steed PM, O'Brien C et al. Dominantnegative inhibitors of soluble TNF attenuate experimental arthritis without suppressing innate immunity to infection. J Immunol 2007; 179: 1872-1883.

30. Hitomi J, Christofferson DE, Ng A, Yao J, Degterev A, Xavier RJ et al. Identification of a molecular signaling network that regulates a cellular necrotic cell death pathway. Cell 2008; 135: 1311-1323.

31. Zhang S, Lin ZN, Yang CF, Shi X, Ong CN, Shen HM. Suppressed NF-kappaB and sustained JNK activation contribute to the sensitization effect of parthenolide to TNF-alpha-induced apoptosis in human cancer cells. Carcinogenesis 2004; 25: 2191-2199.

32. Das M, Sabio G, Jiang F, Rincon M, Flavell RA, Davis RJ. Induction of hepatitis by JNK-mediated expression of TNF-alpha. Cell 2009; 136: 249-260. 
33. Devin A, Lin Y, Liu ZG. The role of the death-domain kinase RIP in tumour-necrosis-factorinduced activation of mitogen-activated protein kinases. EMBO Rep 2003; 4: 623-627.

34. Eferl R, Wagner EF. AP-1: a double-edged sword in tumorigenesis. Nat Rev Cancer 2003 3: 859-868.

35. Kresse M, Latta M, Kunstle G, Riehle HM, van Rooijen N, Hentze $\mathrm{H}$ et al. Kupffer cell-expressed membrane-bound TNF mediates melphalan hepatotoxicity via activation of both TNF receptors. J Immunol 2005; 175: 4076-4083.

36. Baud V, Karin M. Signal transduction by tumor necrosis factor and its relatives. Trends Cell Biol 2001; 11: 372-377.
37. Ding J, Huang $\mathrm{Y}$, Ning B, Gong W, Li J, Wang $\mathrm{H}$ et al. TNF-alpha induction by nickel compounds is specific through ERKs/AP-1-dependent pathway in human bronchial epithelial cells. Curr Cancer Drug Targets 2009; 9: 81-90.

38. Mackay HJ, Twelves CJ. Targeting the protein kinase $\mathrm{C}$ family: are we there yet? Nat Rev Cancer 2007; 7: 554-562.

39. Newton AC. Protein kinase C: structure, function, and regulation. J Biol Chem 1995; 270: 28495-28498.

40. Moretti L, Kim KW, Jung DK, Willey CD, Lu B. Radiosensitization of solid tumors by Z-VAD, a pan-caspase inhibitor. Mol Cancer Ther 2009; 8: 1270-1279.

Supplementary Information accompanies the paper on Cell Death and Differentiation website (http://www.nature.com/cdd) 